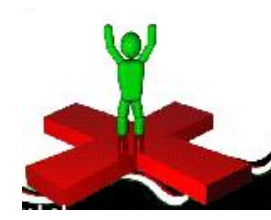

\title{
Detection of deletion mutation in the central hotspot region of the dystrophin gene using multiplex polymerase chain reaction technique
}

\author{
S.A. FARGADE, M.R. SHELKE AND R.V. DARADE
}

See end of the paper for authors' affiliation

Correspondence to : S.A. FARGADE

College of Agricultural Biotechnology, Loni, AHMEDNAGAR (M.S.) INDIA Email:

F.sarika777@gmail.com
ABSTRACT : Duchenne Muscular Dystrophy (DMD), the most common genetic neuromuscular disease of childhood is caused by deletions, duplications or point mutations of the dystrophin gene located at Xp 21.2. DMD is an X-linked recessive genetic disease which is characterized by progressive muscle weakness and degeneration of skeletal muscle. Most of the deletions occur in two hotspot regions present at the 5' end or the central region of dystrophin gene. The study focused on the deletion mutations in the central region of the dystrophin gene specifically exons $34,42,44,47,48,51,52$. Multiplex polymerase chain reaction was standardized for these exons in control samples of normal female. Two clinically diagnosed DMD patients were analyzed using this standardized protocol to detect deletions in these particular exons. The multiplex PCR conditions for exon 34, 42, 44, 47, 48, 51 and 52 in the central region of dystrophin gene were standardized. Out of the two patient samples analyzed in which patient 1 showed deletion of exon 47 and 52 in the dystrophin gene. Deletion analysis of patient 2 did not show any deletion in the above mentioned exons. This resulted in diagnosing deletion mutation in exon 47 and 52 of dystrophin gene.

How to cite this paper : Fargade, S.A., Shelke, M.R. and Darade, R.V. (2014). Detection of deletion mutation in the central hotspot region of the dystrophin gene using multiplex polymerase chain reaction technique. Internat. J. Med. Sci., 7(1\&2) : 7-11.

\section{KEY WORDS :}

DMD, Dystrophin gene, Deletion mutation, $\mathrm{mPCR}$ 